\title{
Assessment of Kara Abattoir Effluent on the Water Quality of Ogun River, Nigeria
}

\section{*ADESINA, AO; OGUNYEBI, AL; FINGESI TS; OLUDOYE, OO}

Department of Cell Biology and Genetics, University of Lagos, Akoka, Lagos, Nigeria

*Corresponding Author Email: writetotomiadesina@gmail.com, justinafingesi@yahoo.com, 08139263829

\begin{abstract}
Direct discharge of abattoir effluents into water bodies contributes to problem of water pollution. This study assessed the impact of Kara Abattoir effluents on Ogun River in Nigeria using standard methods to measure the physiological characteristics and heavy metal levels. The results made it evident that most of the chemical parameters in this study exceeded the accepted standards; phosphate was seen to range between $0.34-109 \mathrm{mg} / 1$ with a mean value of $27.62 \mathrm{mg} / \mathrm{l}$. All the twelve heavy metals observed in the water samples were within acceptable limits. The most alarming result observed is the presence of a "too many to count" range of microbial load and faecal coliform which can be attributable to a major cause of diarrhoea, urinary tract infections, respiratory illness and other threat to human heath. Ogun River serves as habitat to some organisms; and is also used for domestic activities by nearby communities; hence, urgent policy implementation is required.
\end{abstract}

\section{DOI: https://dx.doi.org/10.4314/jasem.v22i9.17}

Copyright: Copyright (C) 2018 Adesina et al. This is an open access article distributed under the Creative Commons Attribution License (CCL), which permits unrestricted use, distribution, and reproduction in any medium, provided the original work is properly cited.

Dates: Received: 30 April 2018; Revised: 23 July 2018; Accepted: 30 September 2018

Keywords: Abattoir, Effluents, Ogun River, Pollution

Pollution of water bodies has become a bane in the society due to the inability to properly manage wastewater as a result of extensive industrialization, increasing population density and high urbanized societies (Bhattacharya. and Bolaji, 2010). It reduces the potential of water as a resource; this is because pollution causes the water to become unsuitable for various uses and also makes it difficult and more expensive to treat to acceptable quality for use (Terrumun and Oliver, 2015). Wastewaters are usually released from abattoirs directly into the ecosystems without adequate treatment process thereby posing serious threats to surface water quality, general environmental safety and health (Tekenah et al., 2014). Such water pollution disturbs the balance of the ecosystem, resulting in the death of various animal and plant species present in the water. Abattoir based pollutants usually comprise of animal blood, paunch manure, animal faeces, animal horns, bones, spent oil from machines like generators etc. (Ogbomida et al., 2016). Abattoir effluents increase levels of nitrogen, phosphorus, total solids in receiving water bodies leading to eutrophication (Omole and Longe, 2008). These organic effluents frequently contain large quantities of suspended solids which reduce the light available to photosynthetic organisms (Raheem and Morenikeji, 2008). Animal blood has a high BOD; cattle for example has a BOD of $156,500 \mathrm{mg} / \mathrm{l}$ and COD of $218,300 \mathrm{mg} / 1$, this implies that there will be a reduction in the dissolved oxygen (DO) of the aquatic environment hence leading to death in aquatic organisms. Improper disposal systems of wastes from slaughter houses could lead to transmission of pathogens to humans and cause zoonotic diseases such as Bacillosis, Brucellosis, Salmonellosis etc. (Smith et al., 2015). Contamination of natural water bodies has emerged as a major challenge in developing and densely populated countries like Nigeria (Ezekoye $e t$ al., 2013). Estuaries and inland water bodies, which are the major sources of drinking water in Nigeria, are often contaminated by the activities of the adjoining populations and livestock processes; of specific concern are abattoir facilities. Water bodies serve as a means of discharge for several abattoirs; the crux of the matter lies with the fact that in several developing nations, untreated wastes is being discharged into water bodies and this compromise the water quality and increases the dangers that could be posed to human lives and other aquatic organisms (Adeyemo et al., 2002).

This study analysed the water samples, by assessing the physiochemical quality, identifying the microbial load and determining the level of heavy metal contamination. Saidu and Musa, 2012 studied the impact of abattoir effluent on River Landzu, Bida, Nigeria; results obtained showed that most of the samples were above the WHO standard which makes the river water unsafe to both human and aquatic life. Also, (Weobong and Adinyira, 2011) in their study of 
the operational impacts of the Tamale abattoir on the environment in Ghana reported the effluent was highly polluted and did not meet the set standards for effluent discharge into the environment. Chukwu et al., 2008 examined the effect of Minna abattoir on surface water quality, the result of the water analysis showed variations with WHO allowable limits. Based on these results, it was concluded that abattoir effluents lowered the quality of the receiving stream. (Ezekoye et al., 2013) during their study at Ijebu-Igbo abattoir reported that waste water from the butchering section had a higher bacteria count of $3.20 \times 10^{6} \mathrm{cfu} / \mathrm{ml}$ than waste water from the rinsing section with $2.21 \mathrm{x}$ $10^{6} \mathrm{cfu} / \mathrm{ml}$. Bacteria isolated from both waste water and soil sample include Escherichia coli, Klebsiella pneumonia, Staphylococcus aureus, Proteus mirabilis, Serratia sp., Pseudomonas putida, Enterobacter aerogenes. Ogun River serves as a receiving body for effluents from the popular meat market, Kara abattoir adjoining the region. Ogun River not only serves as a habitat to some organisms but also as a source of livelihood; transportation, fishing and domestic usage to individuals around its community. Therefore, the objective of this study is to evaluate the influence of Kara Abattoir effluents on the water quality parameters on River Ogun, Nigeria.

\section{MATERIALS AND METHODS}

Study Area: The Ogun River basin is located in the southern part of Nigeria with latitudes $6^{\circ} 26^{\prime} \mathrm{N}$ and $9^{\circ} 10^{\prime} \mathrm{N}$ and longitudes $2^{\circ} 28^{\prime} \mathrm{E}$ and $4^{\circ} 8^{\prime} \mathrm{E}$. About $2 \%$ of the basin area falls outside Nigeria in the Benin Republic. The land area is about $23,000 \mathrm{~km}^{2}$. Ogun River flows southwards over a distance of about $480 \mathrm{~km}$ before it discharges into the Lagos Lagoon (Bhattacharya and Bolaji, 2010). The Ogun River is used for Fishing, Domestic use, Car wash, Transportation, Recreation among other purposes.

Field Survey and Sampling: The field survey was carried out over a kilometre distance of the Ogun River from Opic to Kara Abattoir. The point source of the pollution into Ogun River from Kara abattoir was also identified. The water samples were immediately transported to the Waste water Laboratory, Lagos State Environmental Protection Agency (LASEPA) Lagos, for analysis of the sample.

Sampling Location: Samples were taken between the hours of 6am - 9am which is the peak pollution period that butchers start slaughtering. The sampling points were selected over a distance of $100 \mathrm{~m}$ from the discharge point into the Ogun River:

Sample Point 1 (Lat 06039.1'N / Long 003023.1'E): This point is located upstream from the point source (a hundred metres from the point source). It was taken as the control sample used to reflect the ambient state of the water body.

Sample Point 2 (Lat 06038.8'N / Long 003022.8'E): This is the actual point where the effluent from the abattoir discharges into the river body. It is a direct effluent filled with blood, faeces, urine, and hair from the slaughtered animals. The water had a murky appearance.

Sample Point 3 (Lat 06038.75'N / Long 003022.8'E): This is located 20metres downstream from the point source of the discharged effluent. The water was quite clear but with particles in it.

Sample Point 4 (Lat 06038.75'N / Long 003022.81'E): This is located 40metres downstream from the point source of the discharged effluent. At the point, the water had a clearer appearance but not without particles.

Colour and Appearance: Sample was shook vigorously for homogeneity and dispensed into a glass beaker. $10 \mathrm{ml}$ of the sample was filtered and the colour was read using a spectrophotometer; the clearer the sample, the lower the value recorded.

pH, Temperature, Conductivity, Total Dissolved Solids: The water samples were dissipated into beakers and then calibrated, the probe of the multimeter was inserted into the beaker. Each sample was read for the specific parameters taken as displayed on the LED display.

Total Solid: The crucible was washed, dried, cooled off, weighed and recorded as the initial weight. Ionized water was used to rinse the crucible; $50 \mathrm{ml}$ of the water sample was dispensed into the crucible; which was then oven-dried for about 48hrs. After drying, the crucible was cooled off and weighed again. The initial weight was then subtracted from the final weight.

Total Suspended Solids: The meter was calibrated by using ionized water to rinse the probe, and water sample was dispensed into beakers. The probe from the TSS portable hand-held system was then used to take the readings.

Dissolved Oxygen: The Dissolved Oxygen meter was calibrated and the wastewater sample was gently dispensed into the beaker, the probe was then inserted into the beaker and the reading was taken.

Chemical Oxygen Demand: The samples were filtered through $0.45 \mathrm{~mm}$ filter to remove biological 
interference. $2 \mathrm{ml}$ of the sample was then pipette into a reagent vial. The vial was inverted several times till it got hot. The vials were then placed in the COD reactor at $150^{\circ} \mathrm{C}$ for 2 hours. After which, the samples were cooled and set in the spectrophotometer, through which the values were read.

Oil and Grease: A 100ml of the sample was measured into the conical flask. 2-3 drops of Nitric acid was added into the sample in order to break down complex bonds. This was followed by adding $100 \mathrm{ml}$ of diethyl ether into the sample, stirred vigorously and poured into a separating funnel. The first layer separated was the diethyl ether; the middle layer consisted of the oil and grease while the last layer was the water sample. Some of the water sample was decanted into the conical flask, placed in the water bath and allowed to complete dryness. After drying, it was reweighed and subtracted from the tar weight to get the weight of the oil and grease.

Total Acidity and Alkalinity: $100 \mathrm{ml}$ of the sample was pipetted and dispensed into a conical flask, two drops of methyl orange indicator was added to the sample. The burette was then filled with sodium hydroxide. The contents of the flask were then titrated with sodium hydroxide until the sample turned yellow which was recorded as Total Alkalinity. Two drops of phenolphthalein indicator is added to the sample, and titrated with sodium hydroxide until the sample changes to pink, and then the acidity was calculated.

$$
T A=\frac{V_{N a} V_{s} W_{a}}{V_{S} 10}
$$

Where TA = Total Acidity; $\mathrm{V}_{\mathrm{Na}}=$ Volume of Sodium Hydroxide; $\mathrm{V}_{\mathrm{S}}=$ Volume of Sample; $\mathrm{W}_{\mathrm{a}}=$ Weight of Acid

Test for Chloride, Nitrate, Phosphate, Sulphate: The machine was balanced to zero and then a pillow of the reagent for the test was added to the water sample in the cuvette and returned into the spectrophotometer. The value was recorded and the process was repeated for the other reagents and tests.

Biochemical Oxygen Demand: The samples were kept in air tight containers fitted with a pressure sensor. Lithium hydroxide was added into the container to aid absorption of carbon dioxide. As oxygen is consumed, ammonia oxide is inhibited leading to the expulsion of carbon dioxide. This reaction results in a drop in gas and pressure; as the pressure drops, the sensor computes and displays the consumed quantity of oxygen.
Determination of Heavy Metals: Standard stock solutions were prepared from the digested samples in a test tube. The sample was sucked up into a Nebuliser with a capillary tube; when metal being tested for is present, it absorbed some light reducing its intensity, the system then converted the change in intensity into an absorbance and the reading was taken. This procedure was used to test for Calcium, Zinc, Iron, Chromium, Sodium, Manganese, Lead, Cadmium, Potassium, Nickel and Silver using the Atomic Absorption Spectrophotometer.

Total plate count: The conical flask containing the 'standard plate count agar' was flamed using the spirit lamp and dispensed into the already inoculated plates. It was swirled gently and allowed to set, the plates were then inverted and incubated at $37^{\circ} \mathrm{C}$ for 24 hours after which bacterial growth was checked and counted.

Presence of coliform: MacConkey agar was prepared and carefully dispensed into petri dishes that had been inoculated with the water samples and allowed to set. Afterwards, the plates were incubated at $37^{\circ} \mathrm{C}$ for 24 hours and then checked for pink colonies.

Escherichia coli count: Eosin methylene blue agar was flamed using the spirit lamp and dispensed into the already inoculated plates and allowed to set. The plates were then incubated at $37^{\circ} \mathrm{C}$ for 24 hours. The presence of green metallic sheen seen on the plates after subculturing indicated the presence of Escherichia coli and the isolates found were counted.

\section{RESULT AND DISCUSSION}

Effect of Kara Abattoir Effluents on the Physical Properties of Ogun River: The $\mathrm{pH}$ and Temperature of the control sample, 100metres from the abattoir region were statistically similar $(\mathrm{P}>0.05)$ to the $\mathrm{pH}$ and Temperature of the samples from the abattoir region. SPSS and other excel tools were used to validate these analytical results.

From Table 1, the appearance of the water varied due to the concentration of abattoir effluent in that region. Sample 2 taken from the mixing point of the effluent discharge into the river was the most turbid of all the samples. Its colour reading was also the highest at 2,684Pt.Co.APHA which is higher than the acceptable standard. Similarly, the mean value of the colour of the water did supersede the acceptable standard. This result is similar to the work of (Hassan et al., 2014). The $\mathrm{pH}$ of the abattoir wastewater samples was acidic with its values ranging from $5.74-5.9$. 
Table 1: Physical parameters in wastewater samples

\begin{tabular}{|c|c|c|c|c|c|c|c|}
\hline \multicolumn{8}{|c|}{ Physical } \\
\hline \multirow[t]{2}{*}{ Parameter } & \multicolumn{4}{|c|}{ Result } & \multirow[t]{2}{*}{ Mean } & \multirow[t]{2}{*}{ Range } & \multirow{2}{*}{$\begin{array}{c}\text { Lasepa } \\
\text { Standard }\end{array}$} \\
\hline & $\begin{array}{l}\text { Sample } 1 \\
\text { (Control) }\end{array}$ & Sample 2 & $\begin{array}{l}\text { Sample } \\
\mathbf{3}\end{array}$ & $\begin{array}{l}\text { Sample } \\
4\end{array}$ & & & \\
\hline \multirow[t]{2}{*}{ Colour } & 138 & 2.684 & 39 & 131 & 77.671 & $2.684-138$ & 250Pt.Co.APHA \\
\hline & & $\begin{array}{l}\text { Dark } \\
\text { Brown } \\
\text { With }\end{array}$ & $\begin{array}{l}\text { Cloudy } \\
\text { With }\end{array}$ & $\begin{array}{l}\text { Cloudy } \\
\text { With }\end{array}$ & & & \\
\hline Appearance & Cloudy & Particles & Particles & Particles & & & Clear \\
\hline Temperature ${ }^{0} \mathrm{c}$ & 27.6 & 27.3 & 27.6 & 27.6 & 27.525 & $27.3-27.6$ & $<40$ \\
\hline $\mathrm{pH}$ & 5.98 & 5.74 & 5.83 & 5.93 & 5.87 & $5.74-5.93$ & $5.5-9.0$ \\
\hline Turbidity & NA & $\mathrm{NA}$ & NA & NA & & & FTU \\
\hline $\begin{array}{l}\text { uS/cm } \\
\text { Total Suspended }\end{array}$ & 138 & 3.567 & 142 & 135 & 104.64175 & 3.567142 & \\
\hline Soilds $\mathrm{mg} / \mathrm{l}$ & 27 & 6,650 & 39 & 32 & 1687 & $27-6,650$ & 100 \\
\hline $\begin{array}{l}\text { Total Dissolved } \\
\text { Solids mg/l }\end{array}$ & 77 & 1,344 & 143 & 40 & 401 & $40-1,344$ & 2100 \\
\hline Total Solids mg/l & 104 & 7,994 & 182 & 72 & 2088 & $72-7,994$ & 2200 \\
\hline
\end{tabular}

Table 2: Chemical parameters in wastewater samples

\begin{tabular}{|c|c|c|c|c|c|c|c|}
\hline \multicolumn{8}{|c|}{ Chemical } \\
\hline \multirow{2}{*}{ Parameter } & \multicolumn{4}{|c|}{ Result } & \multirow[t]{2}{*}{ Mean } & \multirow[t]{2}{*}{ Range } & \multirow{2}{*}{$\begin{array}{c}\text { Lasepa } \\
\text { Standard }\end{array}$} \\
\hline & $\begin{array}{l}\text { Sample } 1 \\
\text { (Control) }\end{array}$ & $\begin{array}{l}\text { Sample } \\
2\end{array}$ & $\begin{array}{l}\text { Sample } \\
\mathbf{3}\end{array}$ & $\begin{array}{l}\text { Sample } \\
4\end{array}$ & & & \\
\hline Total acidity $\mathrm{mg} / \mathrm{l}$ & 26 & 3,300 & 24 & 34 & 846 & $24-3,300$ & NS \\
\hline Total alkalinity $\mathrm{mg} / \mathrm{l}$ & 100 & 4,500 & 90 & 95 & 1196.25 & $90-4,500$ & NS \\
\hline Chloride $\mathrm{mg} / \mathrm{l}$ & 13 & 300 & 13 & 13 & 84.75 & $13-300$ & 250 \\
\hline Nitrate $\mathrm{mg} / \mathrm{l}$ & 6.8 & 2,395 & 7.7 & 8.1 & 604.4 & $6.8-2,395$ & \\
\hline Phosphate mg/l & 0.5 & 109 & 0.62 & 0.34 & 27.615 & $0.34-109$ & \\
\hline Sulphate mg/l & 0 & 0 & 1 & 3 & 1 & $0-3$ & \\
\hline Phenol mg/l & NA & NA & NA & NA & & & 1.0 \\
\hline Oil and Grease $\mathrm{mg} / \mathrm{l}$ & 12.4 & 741.1 & 15.6 & 5.6 & 193.675 & $5.6-741.1$ & 10 \\
\hline Dissolved Oxygen & 4.83 & 3.09 & 4.14 & 5.09 & 4.2875 & $3.09-5.09$ & $2 \mathrm{mg} / \mathrm{L}(1 \mathrm{~min})$ \\
\hline Chemical Oxygen & & & & & & & \\
\hline Demand $\mathrm{mg} / \mathrm{l}$ & 0 & 3,850 & 29 & 20 & 974.75 & $0-3,850$ & 200 \\
\hline
\end{tabular}

Table 3: Concentration of Heavy metals in Abattoir wastewater samples

\begin{tabular}{|c|c|c|c|c|c|c|c|}
\hline \multicolumn{8}{|c|}{ Trace/Toxic Heavy Metals } \\
\hline \multirow[t]{2}{*}{ Parameter } & \multicolumn{4}{|c|}{ Result } & \multirow[t]{2}{*}{ Mean } & \multirow[t]{2}{*}{ Range } & \multirow{2}{*}{$\begin{array}{l}\text { Lasepa } \\
\text { Standarc }\end{array}$} \\
\hline & Control & Sample 1 & Sample 2 & Sample 3 & & & \\
\hline Calcium mg/l & 0.0384 & 0.2439 & 0.0837 & 0.0911 & 0.114275 & 0.077511 & 200 \\
\hline Zinc mg/l & 0.0004 & 0.0376 & 0 & 0.0052 & 0.0108 & 0.015608 & 5.0 \\
\hline Copper & 0 & 0.0040 & 0.0012 & 0 & 0.0013 & 0.001634 & 3.0 \\
\hline Iron $\mathrm{mg} / \mathrm{l}$ & 0.1415 & 0.7803 & 0.0818 & 0.2971 & 0.325175 & 0.274269 & 10.0 \\
\hline Chromium mg/l & 0.0046 & 0.0065 & 0.0073 & 0.0113 & 0.007425 & 0.002443 & 0.1 \\
\hline Sodium $\mathrm{mg} / \mathrm{l}$ & 0.3195 & 0.5247 & 0.5044 & 0.7798 & 0.5321 & 0.163841 & \\
\hline Manganese $\mathrm{mg} / \mathrm{l}$ & 0.0113 & 0.1522 & 0.0015 & 0.0242 & 0.0473 & 0.061097 & 5.0 \\
\hline Lead $\mathrm{mg} / \mathrm{l}$ & 0 & 0.0016 & 0 & 0 & 0.0004 & 0.000693 & 0.1 \\
\hline Cadmium mg/l & 0.0003 & 0.0002 & 0.0003 & 0.0006 & 0.00035 & 0.00015 & 2.0 \\
\hline Potassium mg/l & 0.3567 & 0.8374 & 0.4094 & 0.5027 & 0.52655 & 0.186929 & 200.00 \\
\hline Nickel mg/l & 0 & 0.0017 & 0 & 0.0015 & 0.0008 & 0.000803 & 3.0 \\
\hline Silver mg/l & 0.008 & 0 & 0 & 0 & & & $<0.10$ \\
\hline
\end{tabular}

Effect of Kara Abattoir Effluents on the Chemical Properties of Ogun River: Phosphate in the sample ranged from $0.34-109 \mathrm{mg} / \mathrm{l}$ with a mean value of $27.62 \mathrm{mg} / \mathrm{l}$ which is higher than the accepted standard of $5 \mathrm{mg} / \mathrm{l}$. Nitrate in the wastewater samples ranged from $6.8-2,395 \mathrm{mg} / \mathrm{l}$ with a mean value of $604.4 \mathrm{mg} / \mathrm{l}$ which exceeded the LASEPA standard of $10 \mathrm{mg} / \mathrm{l}$. This result was in line with (Akan et al., 2010) findings on the chemical properties of abattoir wastewater samples in Maiduguri, Nigeria. Nitrate in water bodies could cause Blue Baby syndrome, increased phosphate can also cause excessive aquatic plant growth and algal 
bloom. The presence of water hyacinth was observed in large quantities on the Ogun River. The dissolved oxygen ranged from $3.09-5.09 \mathrm{mg} / \mathrm{l}$ and its mean was $4.29 \mathrm{mg} / 1$. For Biochemical oxygen demand (BOD), it ranges from $0-962.5 \mathrm{mg} / 1$ and the mean was $243.69 \mathrm{mg} / \mathrm{l}$. This is above the accepted LASEPA standard for wastewater; moreover, high Biochemical Oxygen Demand values at the discharge point could be attributed to the low Dissolved Oxygen level, since low Dissolved Oxygen will result in high Biochemical Oxygen Demand and this is a strong indication of pollution (Tekenah et al., 2014). The chemical oxygen demand of the wastewater samples ranges from 0$3850 \mathrm{mg} / \mathrm{l}$ and its mean value is $974.75 \mathrm{mg} / \mathrm{l}$ which is also above the accepted LASEPA standard for wastewater. The Total Suspended Solids (TSS) of the samples ranges from $27-6650 \mathrm{mg} / \mathrm{l}$ and its mean value is $1687 \mathrm{mg} / \mathrm{l}$ which exceeded the acceptable standard for Total Suspended Solids in wastewater samples. The Total solids ranges from $72-7994 \mathrm{mg} / \mathrm{l}$ and its mean value is $2088 \mathrm{mg} / \mathrm{l}$ which also exceeded the acceptable standard. The Total Suspended Solids, Total Dissolved Solids, Biochemical Oxygen Demand and Nitrate of the samples from the control sample are statistically different $(\mathrm{P}<0.05)$ from that in the abattoir region.

Relationship between Total Dissolved Solids and Dissolved Oxygen: An inverse linear correlation was observed between Total Dissolved Solids and Dissolved Oxygen in that as the Total Dissolved solids increase, the dissolved oxygen falls with a correlation of $r=-0.92$. This was in line with (Adie and Osibanjo, 2007) findings.

Relationship between Total Dissolved Solids and Chemical Oxygen Demand: Total Dissolved Solids (TDS) and Chemical oxygen demand (COD) is seen to have a linear correlation in that as Total Dissolved Solids increases, Chemical Oxygen Demand likewise increases at a correlation of $r=0.99$.

Relationship between Total Dissolved Solids and Biochemical oxygen Demand: The relationship between the Total Dissolved Solids and Biochemical Oxygen Demand is a linear correlation indicating that as Total Dissolved Solids (TDS) increases, Biochemical Oxygen Demand (BOD) also increases. The correlation is at $r=0.99$, which is close to what is seen in previous study of (Ojekunle and Lateef, 2017).

Heavy metal concentrations in Ogun River due to Kara abattoir effluent discharge: Heavy and trace metals are of importance in water, living organisms require varying amounts of some of these metals $(\mathrm{Ca}, \mathrm{Co}, \mathrm{Cr}$, $\mathrm{Cu}, \mathrm{Fe}, \mathrm{K}, \mathrm{Mg}, \mathrm{Mn}, \mathrm{Na}, \mathrm{Ni}$ and $\mathrm{Zn}$ ) as nutrients (macro or micro) for proper growth. Other metals (Ag, $\mathrm{Al}, \mathrm{Cd}$, $\mathrm{Au}, \mathrm{Pb}$ and $\mathrm{Hg}$ ) have no biological role and hence are non-essential (Akpor and Muchie, 2011). Their presence in wastewater is due to discharges from residential dwellings, groundwater infiltration, and industrial discharges. From (Table 3), Potassium was the metal with the highest concentration in the wastewater samples, ranging from $0.356-0.837 \mathrm{mg} / \mathrm{l}$ and a mean value of $0.526 \mathrm{mg} / \mathrm{l}$; however it still falls within the acceptable limits. The metal with the least concentration was lead which had a mean value of $0.0004 \mathrm{mg} / \mathrm{l}$ and ranged from $0-0.0016 \mathrm{mg} / \mathrm{l}$. All the metals observed in the water samples were within the acceptable standard for wastewater. The accumulation of these metals in wastewater depends on many local factors, such as way of life and awareness of the impact on the environment through the careless disposal of wastes (Bhattacharya and Bolaji, 2010).

Microbiological analysis of the effluent: Bacteria are the most common microbial pollutants in wastewater. They cause a wide range of infections, such as diarrhoea, dysentery, skin and tissue infections, etc. The tests for total coliform and faecal coliform nonpathogenic bacteria were used to indicate the presence of pathogenic bacteria. Results showed that the Total Plate count ranged from 120 to a too numerous to count (TNTC) range. This implies that the presence of microorganisms in the samples were too loaded hence making it difficult to count them. The presence of coliform in the water sample was also recorded and it could be attributed to abuse of the water by dumping of animal waste into it. Escherichia coli have been implicated in diseases such as diarrhoea, urinary tract infections, respiratory illness, pneumonia etc.

Conclusion: Based on the results from this study, the water has a high presence of microorganisms and further investigation showed that the water possessed faecal coliform all of which are dangerous for human health if consumed. It is imperative that steps are taken to reduce the pollution in this region since it very much relates with public health; strict enactment of laws on the abuse of water bodies; development of waste treatments and public enlightenment should be carried out to ensure that environmental sanitary is maintained to reduce diseases implosion.

\section{REFERENCES}

Adeyemo, OK; Ayodeji, IO; Aiki-Raji, CO (2002). The Water Quality and Sanitary Conditions in a major abattoir (Bodija) in Ibadan, Nigeria. African Journal of Biomedical Research. 5: 51-55. 
Adie, GU; Osibanjo, S (2007). Impact of Effluents from Bodija Abattoir on the Physicochemical Parameters of Oshunkaye stream in Ibadan City, Nigeria. African Journal of Biotechnology. 6(15): 1806-1811.

Akan, CJ; Abdulrahman, FI; Yusuf, E (2010). Physical and Chemical parameters in Abattoir wastewater sample, Maiduguri Metropolis Nigeria. Pacific Journal of Science and Technology. 11(1): 640648.

Akpor, OB; Muchie, M (2011). Environmental and public health implications of wastewater quality. African Journal of Biotechnology. 10(13): 23792387.

Bhattacharya, AK; Bolaji, GA (2010). Fluid Flow interactions in Ogun River, Nigeria. International Journal of Recent Research and Applied Studies. 2(2): 173.43

Chukwu, O (2008). Analysis of Groundwater pollution from Abattoir waste in Minna, Nigeria. Research Journal of Dairy Sciences. 2(4): 74-77.

Chukwu, O; Mustapha, HI; Gafar, HBA (2008). The Effect of Minna Abattoir Wastewater on Surface Water Quality. Environmental Research Journal. 2(6): 334-338.

Ezekoye, CC; Ilusanya, OA; Neboh, HA; Orji, FA (2013). Assessment of Ijebu-Igbo Abattoir Effluent and its impact on the ecology of the receiving soil and river. Journal of Environmental Science, Toxicology and Food Technology 7(5):61.

Hassan, IA; Campbell, C; Ademola, TG (2014). Effect of Abattoir Effluent on surrounding underground water quality: A case study of Governor's Road Abattoir at Ikotun, Lagos State. International Journal of Advances in Pharmacy, Biology and Chemistry. 3(4): 957-965.

Ogbomida, ET; Kubeyinje, B; Ezemonye, IL (2016). Evaluation of Bacterial profile and biodegradation potential of Abattoir wastewater. African Journal of Environmental Science and Technology. 10 (2): 51.
Ojekunle, OZ; Lateef, ST (2017). Environmental Impact of Abattoir Waste Discharge on the Quality of Surface water and Ground water in Abeokuta. Journal of Environmental and Analytical Toxicology. 7: 509. Doi: 10.4172/2161-0525. 1000509.

Omole, DO; Longe, EO (2008). An Assessment of the Impact of the Abattoir Effluents on River Ilo, Ota, Nigeria. Journal of Environmental Science and Technology. 1:56.

Raheem, NK; Morenikeji, OA (2008). Impact of Abattoir Effluents on Surface waters of the Alamuyo stream in Ibadan. Journal of Applied Sciences and Environmental Management. 12(1): 73.

Saidu, M; Musa, JJ (2012). Impact of Abattoir Effluent on River Landzu, Bida, Nigeria. Journal of Chemical, Biological and Physical Sciences. 2(1): 132-136.

Smith, SI; Fowora, MA; Atiba, A; Anejo-Okopi, J; Fingesi, TS; Adamu, ME; Omonigbehin, EA; Ugo-Ijeh, MI; Bamidele, M; Odeigah P (2015). Molecular detection of some virulence genes in salmonella spp isolated from food samples in Lagos, Nigeria. Animal and Veterinary Sciences. 3(1): $22-27$

Tekenah, WE; Agi, PI; Babatunde, BB (2014). Analysis of surface water pollution from abattoirs and the interrelationship between physicochemical properties. (A case study of the New Calabar River). J. Environ. Sci. Toxicol. Food Technol. 8(5): 10-18

Terrumun, KK; Oliver, TI (2015). Assessment of the Impact of Abattoir Effluent on the Water Quality of River Kaduna, Nigeria. World J. Environ. Engineer. 3(3): 87-94.

Weobong, CA; Adinyira, EY (2011). Operational Impact of the Tamale Abattoir on the Environment. J. Pub. Health. Epidemiol.. 3(9): 386-393. 